\title{
GCU
}

Glasgow Caledonian

University

University for the Common Good

\section{Executive shareholding, compensation, and analyst forecast of Chinese firms}

Huang, Wei; Boateng, Agyenim

Published in:

Applied Economics

DOI:

10.1080/00036846.2016.1218432

Publication date:

2017

Document Version

Author accepted manuscript

Link to publication in ResearchOnline

Citation for published version (Harvard):

Huang, W \& Boateng, A 2017, 'Executive shareholding, compensation, and analyst forecast of Chinese firms', Applied Economics, vol. 49, no. 15, pp. 1459-1472. https://doi.org/10.1080/00036846.2016.1218432

\section{General rights}

Copyright and moral rights for the publications made accessible in the public portal are retained by the authors and/or other copyright owners and it is a condition of accessing publications that users recognise and abide by the legal requirements associated with these rights.

Take down policy

If you believe that this document breaches copyright please view our takedown policy at https://edshare.gcu.ac.uk/id/eprint/5179 for details of how to contact us. 
Executive shareholding, compensation, and analyst forecast of Chinese firms

\author{
Wei Huang ${ }^{1, *}$ \\ Agyenim Boateng ${ }^{2}$
}

*Corresponding author.

1. Wei Huang. Nottingham University Business School China, University of Nottingham Ningbo China. 199 Taikang East Road, Ningbo, China. Email: wei.huang@nottingham.edu.cn

2. Agyenim Boateng. Department of Law, Economics, Accountancy and Risk, Glasgow Caledonian University, UK. Email: Agyenim.Boateng@gcu.ac.uk 
Executive shareholding, compensation, and analyst forecast of Chinese firms

\begin{abstract}
We examine the impact of executive and leadership shareholding and cash compensation on analyst forecast error and dispersion as proxies for information asymmetry. We find that firms pay higher compensation (or excess compensation) to executives and directors are associated with higher information asymmetry. The positive association is stronger where executives' and directors' shareholdings are higher. Shareholding appears to facilitate managerial entrenchment and gives highly paid executives/leadership stronger structural power which adversely affects information disclosure leading to larger forecast error and dispersion. These results are robust to different measures of compensation and alternative models controlling for the predictability of firm level earnings. Our findings indicate that executive/director shareholding and compensation do not provide sufficient incentives for information disclosure by Chinese firms.
\end{abstract}

JEL classifications: G3; M4

Keywords: Executive compensation; analyst forecast; information asymmetry; China 


\section{Introduction}

A vibrant strand of literature on firm governance addresses how managerial behavior and compensation affect firm value using ex-post accounting performance and observed market prices, such as Tobin's Q ratio (Firth et al., 2006b; Hu and Zhou, 2008; Yuan et al., 2008). Studies that employ the viewpoint of stock analysts' earnings forecasts in the context of emerging countries such as China are scant. Yu (2010) suggests analysts' consensus earnings forecast represents the market expectations for firm performance and the forecast dispersion is a reflection of uncertainty over cash flows i.e., a proxy for risk. As information intermediaries and external monitors of corporate performance, analysts directly influence security valuation as well as investors' judgement and behavior (Yuan et al., 2008). A recent study by Bai et al. (2016) also support analysts' role as producers of firm-specific information in China's IPO market by documenting that analyst coverage reduces synchronicity during the 2009-2012 period. Moshirian et al. (2009) report that stock prices react strongly to stock analyst recommendations and revisions in emerging markets including China. Recent studies by Haß et al. (2014), Huang and Wright (2015), and Huang (2016) on Chinese listed firms utilize the forecast error of consensus analysts' earnings forecast and the dispersion of forecasts as proxies for information asymmetry to analyze the influence of corporate governance and firm ownership structure on firm level information environment and document a positive relation between governance and information quality. In this paper, we extend prior studies on corporate governance and information asymmetry in China by focusing on an important yet unexplored governance mechanism - executive and leadership ${ }^{1}$ shareholding and compensation. Specifically, we examine the effects of firm executive

\footnotetext{
${ }^{1}$ Executive and leadership encompass executive management, members of board of directors and supervisor boards
} 
and leadership shareholding and compensation on analysts' earnings forecasts and analysts' forecast dispersion. Our argument is that within-firm governance and managerial compensation provide incentives for information disclosure which influences analysts' forecasts. To this end, we utilize the information of analysts' earnings forecasts from a new dataset which compiles firm level forecasts from the top 50 Chinese securities companies whose major business is brokerage, consultancy, sponsoring securities offering and listing, and asset management.

Governing boards utilize executive compensation contracts in an attempt to align executive actions with corporate goals (Ashley and Yang, 2004). The exploration of the relationship between executive and leadership shareholding, compensation, and analysts' forecasts in the world's largest emerging market is significant for the following reasons. The nature of Chinese leadership of firms appears to be different from that in Western countries. According to Chen et al. (2011), firm leadership in China mirrors the characteristics of Chinese society: its collectivist culture, social harmony, socialist politics and the associated political connections. The leaders of Chinese firms are predominantly insiders with political connections as most Chinese listed companies have evolved from state owned enterprises (SOEs). The government frequently appoints top executive management and their compensation does not relate to stock returns (Firth et al., 2006a). Such features of firm leadership may result in excessive management power which may adversely affect performance, information quality, distort the use of pay as incentive device to improve performance and exacerbate agency problems. Conversely, it may be argued that executive ownership better aligns the interests of managers and that of shareholders thereby improving 
information quality and firm value (Jensen and Meckling, 1976; Han et al., 2014). Despite the conflicting views on the effects of managerial ownership, we know relatively little regarding the association between Chinese firm executive/leadership ownership and analyst forecasts and forecast dispersion (see Han et al., 2014). In addition to executive ownership, studies on the structure of executive compensation such as Ashley and Yang (2004) reveal that the effect of high earnings persistence results in firms that focus more heavily on cash compensation (salary and bonus) rather than on equity compensation (stock options, etc.) due to earnings targeting. It is uncertain how the level of cash compensation may affect earnings persistency and predictability in China where executive compensation is predominantly in cash forms (Chen et al., 2011). For the above reasons, the study on executive ownership, compensation, and analysts' forecasts in the Chinese market is particularly timely as agency theory suggests that executives/leadership ownership and compensation schemes may serve to either mitigate (alignment effects) or exacerbate (entrenchment effects) agency conflicts and affect the analysts' information environment (Chung et al., 2015; Han et al., 2014).

The sheer size of Chinese stock markets and the continual opening of the stock markets to international investors warrant an examination of how corporate governance mechanisms affect investors' expectations. The use of information asymmetry proxies based on analysts' earnings forecasts in the Chinese emerging market is timely because information asymmetry appears to be more severe in emerging countries due to weak corporate governance systems. Thus the use of information asymmetry proxies represents an important departure from the previous studies that have used only realized 
earnings data and measures based on market values to directly assess the influence of executive compensation and managerial ownership on firm value (Firth et al, 2006b; Hu and Zhou, 2008; Yuan et al., 2008). From a broader perspective, this study contributes to executive management shareholding, compensation and agency theory discourse which has attracted intense debate predominantly in advanced market economies with relatively little attention in emerging economies such as China. Specifically, this paper contributes to the literature that investigates the role of executive shareholding and compensation on analysts' information environment. We document that excess compensation to executives is associated with information asymmetry and analyst forecast dispersions. In addition, we add to the understanding of the link between managerial ownership, cash compensation and analyst forecast information in the world's largest emerging market. The focus of analyst forecast information is interesting and significant because analysts represent important outside governance mechanisms that is neither directly controlled by the firm nor entirely environmentally determined (see Lang et al., 2004). In this regard, the study sheds lights on how analysts, an important external monitoring group, incorporate within-firm governance mechanisms particularly executive management shareholding and cash compensation, into their earnings forecasts.

The remainder of this study is structured in the following way. The next section introduces briefly the background literature and develops the hypotheses of the study. A general description of our research approach is also provided in light of these governance features. Section 3 describes the data and methodology. Section 4 comprises the results and discussions, followed by a brief conclusion in section 5 . 
2. Background literature and hypotheses development

\subsection{Related literature}

Corporate governance generally constitutes the set of complementary mechanisms that help to align the actions and decisions of top managers with the interests of shareholders. According to agency theory (Jensen and Meckling, 1976), when the shareholders are too diffused to monitor the managers, corporate assets can be used for the benefit of the managers rather than for maximizing shareholder wealth. It is well documented that one way of resolving this problem is to align the interests of managers and shareholders by offering managers equity stake in the firm (Jensen and Meckling, 1976). Consistent with the alignment view of managerial ownership, executive shareholding reduces information risk in financial reporting ( $\mathrm{Yu}, 2008)$. Byard et al. (2006) also argue that aligning the interests of managers and shareholders reduces the information asymmetry between them and improves the quality of information available to users of financial reports (e.g., financial analysts). The resultant quality of governance should correlate positively with the analysts' forecast accuracy and reduce forecast dispersion. Avramov et al. (2009) suggest that forecast dispersion, which measures uncertainty about the next year's earnings, is an important component of asset valuation and negatively related to future stock returns. Yu (2010) also argues that the disclosure of corporate governance information affects analysts' forecast bias and reduces forecast dispersion. In line with the above evidence mostly documented in the US market, two recent studies by Haß et al. (2014) and Huang and Wright (2015) on Chinese firms also find an association between corporate governance and information asymmetry. 


\subsection{Executives, leadership shareholding, and analyst forecast}

Relatively few studies have examined the effects of firm governance structure on corporate disclosure practices and analyst forecasts (see Karamanou and Vafeas, 2005; Chung at al., 2015). However, recent evidence documented by $\mathrm{Haß}$ et al. (2014) and Huang and Wright (2015) suggest that better governance increases the quality of disclosure and the predictability of earnings among Chinese firms. Under agency theory, there are two conflicting views regarding the effects of managerial ownership on firm value: entrenchment and alignment effects. The entrenchment view suggests that managerial ownership can lead managers to pursue their personal goals at the expense of other shareholders (Shleifer and Vishny, 1989). The entrenchment hypothesis therefore suggests a positive relationship between the managerial ownership and information asymmetry. On the other hand, the alignment hypothesis indicates that managerial equity ownership serves to align the interests of executive management and outside equity holders and mitigate the agency costs associated with the separation of ownership and control (Jensen and Meckling, 1976). According to alignment hypothesis, when executive managers' interests are aligned with those of the shareholders, they become more committed and take actions to maximize firm value (Jensen and Meckling (1976). One of such actions taken by managers is to influence a firm's information environment by improving public disclosure quality through the provision of additional and credible financial information (Han et al., 2014). Han et al. (2014) find managerial shareholding as an important internal monitoring function, which may improve a firm's value and reduce information asymmetry. Despite the competing views on the effects of managerial ownership, there appears little evidence 
regarding the relationship between the managerial ownership and the analyst forecast accuracy and forecast dispersion (Han et al., 2014). To the extent that managerial ownership aligns the interests of the leadership group of Chinese firms to shareholders' interests, we expect executives and leadership ownership to improve disclosure quality and reduce forecast dispersion as such information form a basis of the analysts' expectation of future firm performance (Abarbanell and Bushee, 1997). In this study, we examine the effects of top executive and firm leadership shareholdings which include all executives, the board of directors and supervisors on analyst forecast error and dispersion as proxies of information asymmetry. While using executives' shareholding is common in prior literature, the use of shareholdings of general firm leadership groups appears appropriate for the Chinese settings to ensure robustness of our findings since they tend to play more coordinated roles to help build consensus around firm strategies (Shan and McIver, 2011). Such features of firm leadership in China may lead to policy stability and implementation and better corporate disclosure. In the light of the above argument, we hypothesize a negative association between executive and leadership shareholding and asymmetry:

H1a: Executive and leadership shareholdings decrease analysts' forecast error H1b: Executive and leadership shareholdings decrease analysts'forecast dispersion

2.3 Executives, leadership compensation and analyst forecast

The Code of Corporate Governance for Listed Firms in China recognizes the use of cash incentive-based bonus pay and CEO compensation as means of minimizing conflict of interest between managers and shareholders (Firth et al., 2006a). The 
executive management pay in China is primarily made up of cash compensation with very few firms using executive stock option schemes with very limited disclosures. ${ }^{2}$ While a number of studies have examined managerial incentive schemes in China, evidence suggests that the relationship between cash compensation and firm performance is mixed (Firth et al., 2006a; 2007). The type of compensation scheme used by a firm has strong implications for agency costs. For example, managers who are compensated by a salary and cash bonus plan may have a shorter decision-making horizon than those who are compensated by a long-term stock option. From the standpoint of agency theory, Healy (1985) argue that managers on short-term rather than long-term compensation plan (e.g. share option) have incentives to engage in earnings management activities which improve short-term profits and reduce the quality of financial reporting and increases information asymmetry (Dechow and Dichev, 2002). The above evidence generally indicates high executive and leadership compensation in China increases agency conflict and reduces information transparency which in turn reduces analyst forecast accuracy and increase forecast dispersion. In light of above, we put forward the following hypotheses:

H2a: Executive and leadership cash compensation is positively related to analysts' forecast error.

H2b: Executive and leadership cash compensation is positively related to analysts' forecast dispersion.

\footnotetext{
${ }^{2}$ Prior to 2005, executive compensation was mostly cash as CSRC did not allow managerial shareholding. From July 2005, the CSRC (2005a) allowed publicly traded firms that had successfully completed structural reforms to allow their top management, board members and supervisory board members to own shares.
} 
The literature on executive compensation and performance has also examined through the lens of managerial power (Bebchuk and Weisbach, 2010). The managerial power approach views executive compensation as an outcome of close interpersonal relationships and negotiations between powerful corporate executives, especially CEOs, and weak corporate boards, which leads to the creation of inefficient managerial contracts that magnifies agency problems by increasing the conflict of interests between managers and shareholders (Bebchuk and Weisbach, 2010). Under managerial power approach, the literature indicates that the highly paid executives tend to have more power to pursuit self-interests and this power may encourage managers to reduce information disclosure which exacerbates agency problems. This strand of literature suggests that the predicted component of compensation arises from the characteristics of board and ownership structure in addition to factors such as firm size and performance. Typically, the prediction error, namely the excess compensation, is used as a proxy for management power (Chen et al. 2010a). A number of researchers such as Core et al. (1999), Brick et al. (2006), Chung et al. (2015) adopted similar measurement technique and suggest that excess compensation is associated with greater agency problems and poor firm value. A counter argument here may be referred to as the "investor adverse selection" view on the association between excess compensation and firm information disclosure suggested by Chung et al. (2015). Under this view, they argue that firms which pay higher executive compensation may be subjected to higher market scrutiny to increase disclosure in order to avoid investors' adverse selection. We are interested in the association between excess compensation and information asymmetry in the Chinese market relative to the general perception of the corporate governance quality 
documented earlier. Although the aforementioned competing arguments do not provide a clear prediction for Chinese firms, we posit the following hypotheses:

H3a: Excess executive and leadership cash compensation is positively related to analysts' error.

H3b: Excess executive and leadership cash compensation is positively related to analysts' forecast dispersion.

3. Data and methodology

3.1 Data and variables

Data on executive and firm leadership shareholdings are collected from the China Stock Market and Accounting Research (CSMAR) database for all A-share non-financial listed companies. The statistics, based on the available information for the years $2007-$ 2012, are reported in Table 1 . Approximately $1 / 2$ and $2 / 3$ of the firms-year observations have zero executive and zero overall firm leadership shareholding, respectively. Among the observations with positive shareholdings, executive management shareholding is approximately $4.46 \%$ while overall leadership shareholding constitutes approximately $6.94 \%$.

(Insert Table 1 here please)

We collect consensus analysts' forecasts from systems provided by Wind Information Co., Ltd (WIND). WIND compiles the analysts' earnings forecasts for Chinese A shares listed companies from the top 50 securities companies in China. Approximately $1 / 3$ of 
the listed firms are covered by analysts each year. We exclude firms in the financial industry due to different nature of assets and liabilities. Due to major changes to financial reporting standards in 2007, financial years prior to 2007 are not examined in

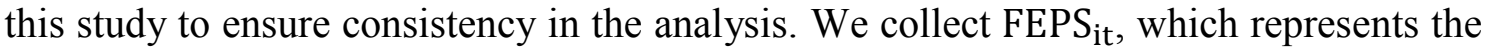
one-year forward forecast of earnings per share for financial year $t$ calculated as the average forecasts made by the security companies within a 90 day window up to the end of July of each year. Thus, these forecasts reflect the most recent financial report information $^{3}$. We exclude observations for which only 1 individual security company forecast is available to ensure "consensus" forecast is meaningful. In addition, the maximum and minimum values of forecasts made by these institutions are also collected as FMAX and FMIN, respectively. Over the sample period 2007-2012, we obtained 4,257 observations of consensus forecasts and on average each of these consensus values represents forecasts by 6 institutions. Our forecast data compare favorably to the samples used in previous studies such as Ang and Ma (1999), Hu et al. (2008), and Truong (2011) in terms of both size and firm coverage. In addition to earnings forecasts, we also collected the realized earnings per share before extraordinary items denoted as NEPS it from the WIND company financial data; we then construct the following proxy measures of information asymmetry:

Analyst consensus forecast error, ERROR $\mathrm{it}=\left|100 *\left(\mathrm{FEPS}_{\mathrm{it}}-\mathrm{NEPS}_{\mathrm{it}}\right) / P_{i t}\right|$

Analyst forecasts dispersion, DISPERSION ${ }_{\mathrm{it}}=100 *\left(\mathrm{FMAX}_{\mathrm{it}}-\mathrm{FMIN}_{\mathrm{it}}\right) / P_{i t}$

\footnotetext{
${ }^{3}$ The financial year for all Chinese listed firms is the calendar year, and annual reports are published before the end of April.
} 
Both measures are multiplied by 100 and scaled by the price per share at the end of April to ensure consistency when comparing across firms. Since the average number of institutional forecasts for calculating the consensus expectations is 6, we follow Huang and Wright (2015) and Huang (2016) by adopting a "range" measure of forecast dispersion rather than a standard deviation measure. The use of this type of "range" in forecasts as proxy for information asymmetry and earnings uncertainty is common in the literature on company earnings forecast (see Han, 2013 for a review of this literature). Using price deflated error and dispersion measures is consistent with Truong (2011) and Huang and Wright (2015) thus avoiding problems associated with negative earnings compared to alternative measures scaled by realized earning. When we replace the mean analyst forecast with the median analyst forecast from WIND, the results in this study are unchanged.

Other financial and accounting data including executive and firm leadership shareholdings and compensation information are collected from CSMAR and WIND. ${ }^{4}$ The summary statistics of the sample variables incorporated in the paper matched against the available analysts' forecasts are reported in Table 2.

(Insert Table 2 here please)

Table 3 shows pairwise correlations among the variables. Analysts' error is negatively correlated with the corporate governance variables including executive and leadership

\footnotetext{
${ }^{4}$ The mean total cash compensation for the top 3 executives and the total cash compensation for overall leadership of the firm are 1.22 million and 3.25 million Chinese Yuan, respectively.
} 
compensation. Analysts' forecast dispersion is negatively correlated with the per person shareholding but positively correlated with the cash compensation variables. We further explore these relationships in properly controlled regression models in the next section.

(Insert Table 3 here please)

\subsection{Models and methods}

We adopt the following fixed-effects models to test our hypotheses on the relationship between the executive/leadership shareholdings, cash compensation and the level of analysts' consensus forecast error and forecast dispersion:

$$
\begin{gathered}
\text { ERROR }_{\mathrm{it}}=\alpha_{\mathrm{i}}+\beta \text { Shareholding }_{\mathrm{it}-1}+\lambda \text { Pay }_{\mathrm{it}-1}+\gamma \mathrm{X}_{\mathrm{it}-1}+\tau_{\mathrm{t}}+\varepsilon_{\mathrm{it}} \\
\text { DISPERSION }_{\mathrm{it}}=\alpha_{\mathrm{i}}+\beta \text { Shareholding }_{\mathrm{it}-1}+\lambda \text { Pay }_{\mathrm{it}-1}+\gamma \mathrm{X}_{\mathrm{it}-1}+\tau_{\mathrm{t}}+\varepsilon_{\mathrm{it}}
\end{gathered}
$$

The models include fixed firm effects $\alpha_{i}$, fixed time effects $\tau_{t}$, and a disturbance term $\varepsilon_{i t}$. Shareholding $i t$ refers to the percentages of executives' or average leadership shareholding per person variables Ex.SH and L.SH. Variable Pay ${ }_{i t}$ refers to the log of top 3 executives' or average leadership cash compensation per person $\log (\mathrm{Ex} . \mathrm{P})$ and $\log ($ L.P $) .{ }^{5}$ We use the $\log$ transformed compensation values due to log normal distributions of the executive and leadership compensation which is also documented in Table 1. In particular, annual report information on shareholding and cash compensation values are regressed against the observed consensus analysts' forecast error and forecasts dispersion over the 90 days window following the publish of financial reports.

\footnotetext{
${ }^{5}$ Alternatively, we test models using the total leadership cash compensations, and our findings are consistent with the results reported.
} 
We choose the analysts' forecasts made between May and July in calculating the forecast error and dispersion measures and regress against the independent variables at the prior year end to control for endogeneity problems. We recognize that this does not completely alleviate endogeneity problems hence remains a methodological limitation. However, given the lack of appropriate instrumental variables for executives' shareholding and pay, we use fixed effects to control for omitted variables and the lagged variables to control for simultaneity issues. Our methodology is in line with recent studies on Chinese analysts by Haß et al. (2014), Huang and Wright (2015), and Huang (2016).

$\mathrm{X}_{\mathrm{it}}$ refers to a number of control variables that may affect analyst expectations. In order to make an incremental contribution to the literature, it is necessary to control for factors that have already been identified by prior studies to affect the analyst forecast accuracy. Independent directors, concentrated and institutional shareholders play monitoring role and improve the quality of governance within a firm. Soundness of corporate governance is associated with less information asymmetry and forecast accuracy (Karamanou and Vefeas, 2005). Professional investors, block tradable shareholders, independent director monitoring measured by the percentage of institutional investors' shareholding at the past year's end (INS.SH), the percentage of shareholding by top 10 tradable shareholders in total (SH.CON), and the number of independent directors to total number of directors ratio (B.IND), respectively. Following Francis et al. (2004), we control for the innate sources of earning attributes including volatility, firm size, leverage, growth opportunities and profitability. Prior literature suggests that volatility causes forecasting difficulties and produce forecast 
dispersions (Goss and Waegelein, 1993). Stock performance is measured by annual stock volatility as standard deviations of returns (Volatility), and Jensen's alpha measure of excess stock returns against the Shanghai Stock Composite Index (Alpha). Firm size controls for differences in the information environment, as large firms tend to attract more public attention and media coverage (Chen et al., 2010b). Firm size is measured as the log of total market capitalization of both tradable and restricted A and B shares in Chinese Yuan at the end of April LOG(MC)). Firms with high growth opportunities are often cash poor and may prefer the use of noncash compensation such as share options (Roulstone, 2003). Growth potential is measured by the Price-to-book ratio at the end of April $(\mathrm{P} / \mathrm{B})$ and three years historical average growth in earnings (GROWTH). Recent period accounting profitability, measured by return on equity using earnings before extraordinary items (ROE) and earnings quality measured as percentage of earnings from operating activities (EARN.Q). Core et al. (1999) suggest that large firms are difficult to monitor, making earnings difficult to forecast. Leverage is measured as the $\log$ of the value of debt as a percentage of market value of equity at the end of April (LOG(D/E)). Goss and Waegelein, (1993) find firms with higher levels of leverage engage in more manipulation of financial statement leading to more forecast dispersion. We apply the methods proposed in Arellano (1987) and Stock and Watson (2008) to obtain standard errors that are robust to cross-sectional heteroskedasticity and within-panel (serial) correlation by clustering on the panel variable.

For $\mathrm{H} 3 \mathrm{a}$ and $\mathrm{H} 3 \mathrm{~b}$ regarding the influence of excessive cash compensation on analyst forecasts, we follow a model similar to those implemented in Core et al. (1999), Brick et al. (2006), Chung et al. (2015) which suggest that the predicted component of 
compensation arises from the characteristics of board and ownership structure, in addition, to factors such as firm size and performance. We first adopt a fixed-effects model and estimate the expected cash compensation based on determinants including managerial equity shareholding and board independence as measures of managerial structural power in determining their compensations, Tobin's Q ratio as a proxy for firm growth opportunities, return on equity as profitability associated pay reward, and firm size measured by market capitalization.

$$
\begin{aligned}
\log \left(P A Y_{i t}\right)= & \alpha_{i}+\beta 1 * \text { Shareholding }_{i t}+\beta 2 * \operatorname{LOG}\left(\text { Tobin's }^{\prime}\right)_{i t}+\beta 3 * R O E_{i t} \\
& +\beta 4 * \operatorname{LOG}(M C)_{i t}+\beta 5 * B . I N D_{i t}+\tau_{\mathrm{t}}+\varepsilon_{\mathrm{it}}
\end{aligned}
$$

The excess cash compensations for executives and firm leaders are then calculated as the difference between their actual pay minus the expected pay from the model predictions.

$$
\text { Excess } \log \left(P A Y_{i t}\right)=\text { Actual } \log \left(P A Y_{i t}\right)-\mathrm{E}\left[\log \left(P A Y_{i t}\right)\right]
$$

We then incorporate the excess cash compensation values in our models on the consensus analysts' forecast error and analyst' forecast dispersion.

\section{Results}

4.1 Executive and leadership shareholding, compensation, and analyst forecast The results in Table 4 models 1-4 show that executives and leadership shareholding variables (Ex.SH and L.SH respectively) do not exert significant influence on analyst consensus forecast error. Models 5-8 of Table 4 show that executive/leadership 
shareholdings have insignificant impact on the analysts' forecast dispersion. According to interest alignment argument (Jensen and Meckling, 1976) for managerial shareholding, equity ownership reduces conflict of interest (information risk and asymmetry), improves the quality of information available to financial analysts but this appears not to be the case and hence hypotheses $\mathrm{H} 1 \mathrm{a}$ and $\mathrm{H} 1 \mathrm{~b}$ are not supported. The rejection of these hypotheses may be due to the entrenchment effect (Shleifer and Vishny, 1989) of executive/leadership shareholdings. The findings may be explained by the coordinated nature of firm leadership in Chinese firms (Shan and McIver, 2011). The fact that firm executives and insider directors act in a coordinated way may facilitate managerial entrenchment suggesting that executives face little or no scrutiny from independent directors and supervisory board members (Lin et al. 1998; Yuan et al., 2009).

(Insert Table 4 here please)

In terms of executive and leadership group compensation, the coefficients for the compensation variables $\log ($ Ex.P) and $\log ($ L.P) in models $1-4$ appear insignificant, suggesting that higher compensation is not associated with higher information asymmetry as measured by the consensus analyst forecast error. In models 5-8 regarding the forecast dispersion, we find both executive and leadership compensation are positively and significantly associated with forecast dispersion suggesting the presence of severe information asymmetry. These results provide a strong support to hypothesis $\mathrm{H} 2 \mathrm{~b}$. 
As an additional analysis, in models 2, 4, 6, and 8 of Table 4, we further include interactions of executive/leadership shareholding and executive/leadership compensation variables as independent variables in our models. These alternative models allow us to capture the marginal effect of executive/leadership compensation on analyst forecast error and dispersion conditional on the level of executive/leadership shareholding. In line with the recommendation by Brambor et al. (2006) on the importance of interpreting marginal effects for interaction models, we compute the marginal effects as the sum of the coefficients on $\log (E x . P)$ and Ex.SH* $\log (E x . P)$ in model 2 and 6 and the sum of coefficients on $\log ($ L.P $)$ and L.SH* $\log ($ L.P $)$ in models 4 and 8 together with the corresponding standard errors of this sums. Results reported in Table 4 show that these marginal effects are consistently positive and significant. According to these marginal effects, we conclude that executive/leadership cash compensation is positively and significantly associated with analyst forecast error and forecast dispersion where executive/leadership shareholdings are higher. Such results indicate that for firms that pay high cash compensation, executive and leadership shareholdings appear not to provide an effective mechanism to help managers' and shareholders' interests alignment and improve information disclosure. Rather executive and leadership shareholdings appear to facilitate managerial entrenchment and give highly paid executives/leadership stronger structural power which adversely affect information disclosure leading to larger analyst forecast error and dispersion.

An explanation of these findings might be that compensations paid to Chinese executives and board members, which are mostly in the form of cash, are short-term performance based. Executive management therefore are more likely to engage in 
financial statement manipulation (Dechow and Dichev, 2002), disclose less information thereby increasing the analyst forecast error and dispersion. The findings are in line with agency theory. Another plausible explanation may be that of opacity hypothesis which posits that stronger leadership/executive power makes the information environment more opaque. Agency conflicts may increase the potential for the firm leadership to withhold or manipulate information in order to mask inefficiencies and make monetary gains through cash compensation (Bartov and Mohanram, 2004).

4.2 Excess executive and leadership compensation and analyst forecast

Our further analysis in Table 5 takes into account the influences of forecasts using the excess cash compensation components detailed in the previous section.

(Insert Table 5 here please)

We notice in models 1 and 2 of the table that excess compensation variables: $\log ($ Ex.P) and $\log ($ L.P) are insignificantly associated with the consensus analyst forecast error. Hypothesis H3a is not supported. Moreover, as the coefficients on excess compensation in these models are statistically insignificant, results so far do not provide a clear support to either the managerial power view (Bebchuk and Weisbach, 2010) or investor adverse selection view (Chung et al., 2015) on the association between excess compensation and information disclosure. Regarding our analysis on the dispersion of analysts' forecasts reported in the models 3-4 of Table 5, we find a positive and significant association between excess compensation variables and forecast dispersion. These results give strong support to the managerial power view on the association 
between executive/leadership compensation and firm information disclosure. Contrary to argument put forth by Chung et al. (2015) that firms which pay higher executive compensation may also be subject to higher market scrutiny to increase disclosure in order to avoid investor adverse selection, our results on Chinese firms show that firms which pay excess executive compensation are not subject to stronger pressures to lower information asymmetry.

Regarding the influence of the control variables in our models, we generally find forecast error and forecast dispersion are negatively associated with Jensen's Alpha, LOG(MC), ROE, and P/B suggesting lower information asymmetry for firms with good stock return performance, larger firms, high profitability firms, and high market valuation firms. The results are in line with the recent study by Han et al. (2014) who found a negative and significant relationship between firm size, growth firms and the amount of information available about the firm in general. However, leverage is positively associated with information asymmetry.

\subsection{Further robustness tests}

To ensure the validity of our findings, we perform two sets of robustness tests in Table 6. We show robustness tests using scaled excess compensation measures in Panel A and results further controlling for the predictability of earnings using a random-walk model in Panel B. In panel A, the excess compensation measures are computed using executive cash pay scaled by the firm market capitalization Ex.P/MC and the leadership cash pay scaled by the firm market capitalization L.P/MC, respectively. The compensation prediction model follows that of Table 5. Regression results appear indifferent from 
those reported in Table 5 and confirm that firms pay higher excess compensation to executives and directors are associated with higher information asymmetry irrespective of the scaled compensation measures used here.

In panel B, we follow Huang and Wright (2015) on the predictability of firm level earnings using a random-walk earnings prediction model based on 1-year lagged earnings per share Lag1_EPS and dividend yield D/P. In addition, we further control for the percentage of non-tradable state-shares and legal person shares in the models as Huang and Wright (2015) suggest non-tradable state shares determine earnings forecast quality. Other control variables follow table 5 regressions. Results reported are consistent with those reported in Table 5 and confirm that the random-walk model performs well in earnings prediction. After controlling for the random-walk model, excess compensation still indicates a positive association with higher forecast dispersion.

\section{Conclusion}

In this paper, we investigate the impact of top executives and firm leadership shareholdings and cash compensation on analyst consensus forecast error and forecast dispersion as proxies for information asymmetry. We argue that consensus and goal congruence among Chinese firm leadership empowers executive management and exacerbates agency costs. Analysts as an external corporate governance mechanism follow closely information on corporate governance and their earnings forecasts reflect the effects of within-firm governance quality, particularly firm level information environment. We show that top executives and the average leadership shareholdings per 
person have insignificant influence on information asymmetry. This indicates that the alignment effect of managerial shareholding appears weak and facilitate managerial entrenchment among Chinese firms given lower levels of managerial shareholding and calls for regulatory and investors' attention.

We further test executive and leadership compensation from the perspective of managerial power and our results are in line with the managerial power view on excess executive compensation (Core et al., 1999; Brick et al., 2006; Chung et al., 2015). We find that both cash compensation and excess cash compensation exert no influence on analyst forecast error suggesting firms which pay high executive and leadership compensation are not under pressure, internal or external, to disclose more information. When considering interaction between executive/leadership compensation and shareholding in our models, we further find that executive/leadership cash compensation is positively and significantly associated with analyst forecast error where executive/leadership shareholdings are higher. We also document a positive effect of compensation and excess compensation on analyst forecasts dispersion which strongly indicates increased information asymmetry associated with high compensation paying firms. Taken together, these findings suggest stronger managerial structural power is detrimental to firm information environment. The implication is self-evident suggesting executive compensation, mostly paid in the form of cash among Chinese firms, as a means to align the interests of firm leadership and shareholders to reduce agency costs are not too effective because of its short-term nature. 
A limitation of this study is that there is no data available on the proportion of incentive-based managerial payment for Chinese market sufficiently enough for empirical analysis. Hence we follow Core et al. (1999); Brick et al. (2006); and Chung et al. (2015) by relying on the indirectly modeled excess component of managerial cash compensations to proxy for managerial power and agency costs. Along with the fast modernization of the Chinese market, just over 160 firms have already successfully implemented incentives pay reforms up to the end of 2014. We expect the availability of this type of incentives pay data will allow practical empirical tests in the future. We suggest that, future research should incorporate incentives pay reform data to test the extent of the incentive pay reform success and its impact on firm performance and information asymmetry. 
References:

Abarbanell JS, Bushee BJ. 1997. Fundamental analysis, future earnings, and stock prices. Journal of Accounting Research 35(1): 1-24.

Ang JS, Ma, Y. 1999. Transparency in Chinese stocks: A study of earnings forecasts by professional analysts. Pacific-Basin Finance Journal 7: 129-155.

Arellano M. 1987. Computing robust standard errors for within-groups estimators. Oxford Bulletin of Economics and Statistics 49: 431-434.

Avramov D, Chordia T, Jostova G, Philipov A. 2009. Dispersion in analysts' earnings forecasts and credit rating. Journal of Financial Economics 91: 83-101.

Ashley AS, Yang SSM, 2004. Executive compensation and earnings persistence. Journal of Business Ethics 50(4): 369-382.

Bai X, Wang F, Zhang J. 2016. Analyst coverage and stock return synchronicity: evidence from regulation changes in China's IPO market. Applied Economics forthcoming. DOI:10.1080/00036846.2016.1161716.

Bartov E, Mohanram P, 2004. Private information, earnings manipulations, and executive stock option exercises. The Accounting Review 79: 889-920.

Bebchuk LA, Weisbach MS. 2010. The state of corporate governance research. Review of Financial Studies 23: 939-961.

Brambor T, Clark WR, Golder M. 2006. Understanding interaction models: improving empirical analysis. Political Analysis 14: 63-82.

Brick IE, Palmon O, Wald JK. 2006. CEO compensation, director compensation, and firm performance: Evidence of cronyism? Journal of Banking and Finance 12: 403-426.

Byard D, Li Y, Weintrop J. 2006. Corporate governance and the quality of financial analysts' information. Journal of Accounting and Public Policy 25: 609-625.

Chen J, Ezzamel M, Cai Z. 2011. Managerial power theory, tournament theory, and executive pay in China. Journal of Corporate Finance 17, 1176-1199.

Chen J, Liu X, Li W. 2010a. The effect of insider control and global benchmarks on Chinese executive compensation. Corporate Governance: An International Review 18(2): 107-123.

Chen CJP, Ding Y, Kim C. 2010b. High-level politically connected firms, corruption, and analyst forecast accuracy around the world. Journal of International Business Studies 41: 1505-1524. 
Chung H, Judge WQ, Li Y-H. 2015. Voluntary disclosure, excess executive compensation and firm value. Journal of Corporate Finance 32: 64-90.

Core JE. 2001. A review of the empirical disclosure literature: Discussion. Journal of Accounting and Economics 31(1-3):441-456.

Core JE, Holthausen RW, Lacker DF. 1999. Corporate governance, chief executive officer compensation and firm performance. Journal of Financial Economics 51: 371406.

Das S, Levine B, Sivarmakrishnan K. 1998. Earnings predictability and bias in analysts' earnings forecasts. The Accounting Review. 73: 277-94.

Dechow P, Dichev I. 2002. The quality of accruals and earnings: The role of accrual estimation errors. The Accounting Review 77: 35-59.

Firth M, Fung PMY, Rui OM. 2006a. Corporate performance and CEO compensation in China. Journal of Corporate Finance 12: 693-714.

Firth M, Fung PMY, Rui OM. 2006b. Firm performance, governance structure and top management turnover in a transitional economy. Journal of Management Studies 43(6): 1289-1330.

Firth M, Fung PMY, Rui OM. 2007. How ownership and corporate governance influence chief executive pay in China's listed firms. Journal of Business Research 60: 776-785.

Francis J, LaFond R, Olsson PM, Schipper K. 2004. Costs of equity and earnings attributes. The Accounting Review 79(4): 797-833.

Haß LH, Vergauwe S, Zhang Q. 2014. Corporate governance and the information environment: Evidence from Chinese stock markets. International Review of Financial Analysis 36: 106-119.

Han J. 2013. A literature synthesis of experimental studies on management earnings guidance. Journal of Accounting Literature 31: 49-70.

Han S, Jin YJ, Kang T, Lobo G. 2014. Managerial ownership and financial analysts' information environment. Journal of Business Finance and Accounting 41(3\&4): 328362

Healy P. 1985. The effect of bonus schemes on accounting decisions. Journal of Accounting and Economics 7: 85-108.

Hu Y, Lin TW, Li S. 2008. An examination of factors affecting Chinese financial analysts' information comprehension, analyzing ability, and job quality. Review of Quantitative Finance and Accounting 30: 397-417. 
$\mathrm{Hu}$ Y, Zhou X. 2008. The performance effect of managerial ownership: Evidence from China. Journal of Banking and Finance 32: 2099-2110.

Huang W. 2016. The use of management forecasts to dampen analysts' expectations by Chinese listed firms. International Review of Financial Analysis 45, 263-272.

Huang W, Wright B. 2015. Analyst earnings forecast under complex corporate ownership in China. Journal of International Financial Markets, Institutions and Money 35: 69-84.

Jensen MC, Meckling WH. 1976. Theory of the firm: Managerial behavior, agency costs, and ownership structure. Journal of Financial Economics 3: 305-60.

Karamanou I, Vefeas N. 2005. Association between corporate boards, audit committees, and management earnings forecasts: An empirical analysis. Journal of Accounting Research 43 (3): 453-486.

Lang M, Lins K, Miller D. 2004. Concentrated control, analyst following and valuation: Do analysts matter most when investors are protected least? Journal of Accounting Research 42: 589-622.

Lin JY, Cai F, Li Z. 1998. Competition, policy burdens, and state-owned enterprise reform. American Economic Review 88: 422-427.

Moshirian F, Ng D, Wu E. 2009. The value of stock analysts' recommendations: Evidence from emerging markets. International Review of Financial Analysis 18: 7483.

Roulstone DT. 2003. The relation between insider-trading restrictions and executive compensation. Journal of Accounting Research 41(3): 525-551.

Shan YG, McIver RP. 2011. Corporate governance mechanisms and financial performance in China: panel data evidence on listed non-financial companies. Asian Pacific Business Review 17(3): 301-324.

Shleifer A, Vishny R. 1989. Managerial entrenchment, Journal of Financial Economics 25: 123-139.

Stock JH, Watson MW. 2008. Heteroskedasticity-robust standard errors for fixed effects panel data regression. Econometrica 76: 155-174.

Truong C. 2011. Post-earnings announcement abnormal return in the Chinese equity market. Journal of International Financial Markets, Institutions and Money 21: 637661.

Yuan RL, Xiao Z, Zou H. 2008. Mutual funds' ownership and firm performance: Evidence from China. Journal of Banking and Finance 32(8): 1552-1565. 
Yuan R, Xiao JZ, Milonas N, Zou JH. 2009. The Role of financial institutions in the corporate governance of listed Chinese companies. British Journal of Management 20(4): 562-580.

$\mathrm{Yu}$ F. 2008. Analyst coverage and earnings management. Journal of Financial Economics 88: 245-271.

Yu M. 2010. Analyst forecast properties, analyst following and governance disclosures: A global perspective. Journal of International Accounting, Auditing and Taxation 19(1): $1-15$. 
Table 1: Executive and Leadership Shareholdings

\begin{tabular}{lrrrr}
\hline & \multicolumn{2}{c}{ Executives (Ex.SH) } & \multicolumn{2}{c}{ Total Leadership (L.SH) } \\
& Holding=0 & Holding $>0$ & Holding=0 & Holding $>0$ \\
Obs. & 3891 & 4160 & 2779 & 5272 \\
Mean & & 4.46 & & 6.94 \\
Std. Dev. & 11.12 & & 16.33 \\
Min & 0.00 & & 0.00 \\
Max & & 49.85 & & 65.88 \\
\hline
\end{tabular}

Notes: Statistics are based on available information for all A-share listed companies for the years 2007 2013. Firm leadership is defined as, including all directors, supervisors, and executives. Shareholdings data are collected as the total holdings of all executives and firm leaders. Ex.SH refers to the total of the top 3 executives' shareholding; L.SH refers to the average shareholding percentage per person by firm leadership groups, including directors, supervisors, and executives. 
Table 2: Summary of Variables

\begin{tabular}{|c|c|c|c|c|c|}
\hline Variable & Obs. & Mean & Std. Dev. & Min & Max \\
\hline ERROR & 4210 & 2.39 & 2.93 & 0.03 & 18.96 \\
\hline DISPERSION & 4210 & 1.38 & 1.66 & 0.01 & 8.57 \\
\hline FEPS & 4257 & 0.54 & 0.46 & -0.44 & 5.80 \\
\hline FMAX & 4257 & 0.63 & 0.55 & -0.44 & 6.40 \\
\hline FMIN & 4257 & 0.46 & 0.39 & -0.65 & 5.15 \\
\hline $\log ($ Ex.P) & 4727 & 13.84 & 0.84 & 10.20 & 18.77 \\
\hline $\log (\mathrm{L} . \mathrm{P})$ & 4693 & 4.90 & 0.81 & 1.46 & 8.75 \\
\hline Excess $\log ($ Ex.P) & 4570 & 0.05 & 0.69 & -3.57 & 3.13 \\
\hline Excess $\log ($ Ex.P) & 4571 & 0.05 & 0.67 & -4.56 & 2.50 \\
\hline L.NUM & 4714 & 20.55 & 4.66 & 10.00 & 61.00 \\
\hline NEPS & 4257 & 0.33 & 0.49 & -3.62 & 5.90 \\
\hline INS.SH & 4009 & 29.81 & 23.14 & 0.00 & 82.70 \\
\hline SH.CON & 4730 & 22.19 & 20.57 & 0.51 & 71.67 \\
\hline Volatility & 3888 & 51.82 & 13.88 & 25.41 & 89.90 \\
\hline Alpha & 4025 & 0.26 & 0.41 & -0.53 & 1.64 \\
\hline $\mathrm{P} / \mathrm{B}$ & 4210 & 4.67 & 4.02 & 0.83 & 41.80 \\
\hline ROE & 4254 & 8.65 & 11.36 & -34.94 & 49.16 \\
\hline GROWTH & 3336 & 6.68 & 135.99 & -421.77 & 248.46 \\
\hline EARN.Q & 3369 & 72.39 & 50.92 & -108.93 & 107.59 \\
\hline Tobin's Q & 4241 & 2.07 & 1.27 & 0.82 & 8.77 \\
\hline B.IND & 4221 & 0.36 & 0.05 & 0.09 & 0.67 \\
\hline LOG(MC) & 4210 & 8.58 & 1.18 & 5.72 & 11.84 \\
\hline LOG(D/E) & 4085 & 2.61 & 1.40 & -1.51 & 5.50 \\
\hline Non-Trade & 7073 & 45.63 & 21.91 & 0.00 & 82.00 \\
\hline $\mathrm{D} / \mathrm{P}$ & 8242 & 0.01 & 0.01 & 0.00 & 0.04 \\
\hline
\end{tabular}

Notes: This table reports the summary statistics for the sample used in the regressions. Variables are winsorized at $1 \%$ and $99 \%$. The variable names are: FEPS, average institutional analysts' forecasts during 90 days until the end of April; FMAX, the maximum value of such forecasts; FMIN, the minimum value of such forecasts; $\log ($ Ex.P) is the $\log$ of the total for the top 3 executives' cash compensation in thousands of Chinese Yuan. Log (L.P) is the log of average leadership cash compensation per person in thousands of Chinese Yuan; Excess Log(Ex.P) and Excess $\log ($ L.P) refer to the excess executive and leadership compensation, respectively. L.NUM, total number of directors, supervisors, and executives; NEPS, the actual reported earnings per share before extraordinary items; ERROR, the analysts' consensus earnings forecast error scaled by price per share, ERROR $=|100 *(\mathrm{FEPS}-\mathrm{NEPS}) / \mathrm{pt}|$; DISPERSION, the dispersion in analysts' forecasts scaled by price per share, 100*(FMAX - FMIN)/pt; INS.SH, the percentage of institutional investors' shareholding at the past year's end; SH.CON, the percentage of shareholding by top 10 tradable shareholders in total. Volatility, annual stock volatility as standard deviations of returns; Alpha, Jensen's alpha measure of excess stock returns against the Shanghai Stock Composite Index; P/B, price to book ratio at the end of April; ROE, return on equity using earnings before extraordinary items; GROWTH, three years historical average growth in earnings; EARN.Q, earnings quality measured as percentage of earnings from operating activities; Tobin's Q, calculated as the total market value of the equity and debt divided by the book value of assets excluding intangible assets, calculated using values at the year's end; B.IND., the number of independent directors to total number of directors ratio; LOG(MC), the log of total market capitalization of both tradable and restricted A and B shares in Chinese Yuan at the end of April; $\operatorname{LOG}(\mathrm{D} / \mathrm{E})$, the log of the value of debt as a percentage of market value of equity at the end of April. Non-Trade, the percentage of non-tradable state shares and legal person shares; D/P, the dividend yield calculated as dividend per share divided by the price per share at the end of April. 
Table 3: Pairwise Correlations

\begin{tabular}{|c|c|c|c|c|c|c|c|c|c|c|c|c|c|c|c|c|c|}
\hline & ERROR & DIS. & Ex.SH & $\log ($ Ex.P) & L.SH & $\log (\mathrm{L} . \mathrm{P})$ & L.NUM & B.IND. & INS.SH & SH.CON & Vol. & Alpha & LOG(MC) & $\mathrm{P} / \mathrm{B}$ & ROE & GROWTH & EARN.Q \\
\hline DISPERSION & $0.18^{*}$ & & & & & & & & & & & & & & & & \\
\hline Ex.SH & $-0.08 *$ & $-0.08 *$ & & & & & & & & & & & & & & & \\
\hline $\log ($ Ex.P) & $-0.12 *$ & $0.15^{*}$ & $-0.04 *$ & & & & & & & & & & & & & & \\
\hline L.SH & $-0.08 *$ & $-0.08 *$ & $0.79 *$ & $-0.08^{*}$ & & & & & & & & & & & & & \\
\hline $\log (\mathrm{L} . \mathrm{P})$ & $-0.13 *$ & $0.13 *$ & $-0.02 *$ & $0.93 *$ & $-0.03 *$ & & & & & & & & & & & & \\
\hline L.NUM & -0.00 & $0.16^{*}$ & $-0.11^{*}$ & $0.33^{*}$ & $-0.17^{*}$ & $0.28 *$ & & & & & & & & & & & \\
\hline B.IND & -0.02 & -0.02 & $0.06^{*}$ & $0.06^{*}$ & $0.07^{*}$ & $0.08 *$ & $-0.09 *$ & & & & & & & & & & \\
\hline INS.SH & $-0.13 *$ & $0.10^{*}$ & $-0.05^{*}$ & $0.37 *$ & $-0.08 *$ & $0.37 *$ & $0.12 *$ & $0.04 *$ & & & & & & & & & \\
\hline SH.CON & $-0.06^{*}$ & $0.11^{*}$ & $0.11^{*}$ & $0.05^{*}$ & $0.15^{*}$ & $0.04 *$ & $0.05^{*}$ & $0.03 *$ & $0.21^{*}$ & & & & & & & & \\
\hline Volatility & 0.09 & $-0.09 *$ & 0.02 & $-0.07 *$ & $0.04 *$ & $-0.06^{*}$ & $-0.07 *$ & 0.01 & $-0.07 *$ & $-0.07 *$ & & & & & & & \\
\hline Alpha & $-0.01 *$ & $-0.13 *$ & $0.05^{*}$ & $-0.04 *$ & $0.06^{*}$ & -0.04 & $-0.04 *$ & -0.02 & $-0.09 *$ & $-0.09 *$ & $0.35^{*}$ & & & & & & \\
\hline LOG(MC) & $-0.21 *$ & $0.17 *$ & $-0.10^{*}$ & $0.58^{*}$ & $-0.14^{*}$ & $0.56^{*}$ & $0.37 *$ & $0.10^{*}$ & $0.47^{*}$ & $0.47^{*}$ & 0.01 & -0.02 & & & & & \\
\hline $\mathrm{P} / \mathrm{B}$ & $-0.15 *$ & $-0.17 *$ & $0.22^{*}$ & 0.02 & $0.22^{*}$ & 0.02 & $-0.12 *$ & $0.06^{*}$ & $0.12 *$ & $0.12^{*}$ & $0.33^{*}$ & $0.22 *$ & $0.12^{*}$ & & & & \\
\hline ROE & $-0.17 *$ & $0.07 *$ & $0.03^{*}$ & $0.28 *$ & $0.05^{*}$ & $0.28^{*}$ & $0.07 *$ & -0.01 & $0.24^{*}$ & $0.24 *$ & -0.03 & $0.24 *$ & $0.28^{*}$ & $0.23 *$ & & & \\
\hline GROWTH & -0.52 & 0.02 & $0.01^{*}$ & 0.00 & -0.01 & $0.02 *$ & 0.00 & $0.03 *$ & $0.02 *$ & $0.02 *$ & $-0.02 *$ & -0.02 & 0.02 & 0.00 & 0.02 & & \\
\hline EARN.Q & -0.00 & 0.00 & $0.03 *$ & -0.02 & $0.04 *$ & -0.02 & -0.02 & 0.00 & 0.00 & $0.00^{*}$ & $-0.01 *$ & 0.00 & $-0.05 *$ & 0.01 & 0.04 & $0.27^{*}$ & \\
\hline LOG(D/E) & $0.29 *$ & $0.20 *$ & $-0.20 *$ & $-0.09 *$ & $-0.20 *$ & $-0.09 *$ & $0.13^{*}$ & $-0.05 *$ & $-0.16^{*}$ & $-0.16^{*}$ & $-0.22 *$ & $-0.17 *$ & $-0.13 *$ & $-0.41 *$ & $-0.23 *$ & 0.02 & -0.02 \\
\hline
\end{tabular}


Table 4: Executive and leadership compensation and information asymmetry

\begin{tabular}{|c|c|c|c|c|c|c|c|c|}
\hline \multirow{2}{*}{$\begin{array}{l}\text { Dep. Var. } \\
\text { Model }\end{array}$} & \multicolumn{4}{|c|}{ Forecast error } & \multicolumn{4}{|c|}{ Forecast dispersion } \\
\hline & (1) & (2) & (3) & (4) & $(5)$ & $(6)$ & $(7)$ & $(8)$ \\
\hline \multirow[t]{2}{*}{ Ex.SH } & 0.009 & -0.649 & & & -0.012 & -0.200 & & \\
\hline & $(0.26)$ & $(-1.46)$ & & & $(-1.36)$ & $(-0.71)$ & & \\
\hline \multirow[t]{2}{*}{ Log(Ex.P) } & -0.004 & -0.036 & & & $0.258 * *$ & $0.249 * *$ & & \\
\hline & $(-0.03)$ & $(-0.22)$ & & & $(2.41)$ & $(2.30)$ & & \\
\hline \multirow[t]{2}{*}{ L.SH } & & & -0.512 & -2.929 & & & -0.217 & $-2.048^{*}$ \\
\hline & & & $(1.01)$ & $(-1.51)$ & & & $(-1.04)$ & $(-1.89)$ \\
\hline \multirow[t]{2}{*}{$\log (\mathrm{L} . \mathrm{P})$} & & & -0.026 & -0.070 & & & $0.197 * *$ & $0.174 * *$ \\
\hline & & & $(-0.15)$ & $(-0.42)$ & & & $(2.03)$ & $(2.11)$ \\
\hline \multirow[t]{2}{*}{ Ex.SH*Log(Ex.P) } & & $0.046^{* *}$ & & & & 0.013 & & \\
\hline & & (1.99) & & & & $(0.66)$ & & \\
\hline \multirow[t]{2}{*}{ L.SH*Log(L.P) } & & & & $0.700 * *$ & & & & $0.373^{*}$ \\
\hline & & & & $(1.98)$ & & & & $(1.76)$ \\
\hline \multirow[t]{2}{*}{ L.NUM } & & & 0.014 & 0.017 & & & -0.004 & -0.002 \\
\hline & & & $(0.57)$ & $(0.68)$ & & & $(-0.23)$ & $(-0.15)$ \\
\hline \multirow[t]{2}{*}{ B.IND } & 0.373 & 0.461 & 0.267 & 0.390 & -1.071 & -1.046 & -0.996 & -0.931 \\
\hline & $(0.20)$ & $(0.25)$ & $(0.14)$ & $(0.21)$ & $(-1.07)$ & $(-1.07)$ & $(-1.03)$ & $(-0.98)$ \\
\hline \multirow[t]{2}{*}{ INS.SH } & 0.003 & 0.003 & 0.003 & 0.004 & 0.003 & 0.003 & 0.003 & 0.004 \\
\hline & $(0.71)$ & $(0.75)$ & $(0.86)$ & $(1.03)$ & $(1.29)$ & $(1.31)$ & $(1.24)$ & $(1.37)$ \\
\hline \multirow[t]{2}{*}{ SH.CON } & $0.019 * *$ & $0.019 * *$ & $0.017^{*}$ & $0.018 *$ & 0.002 & 0.002 & 0.003 & 0.003 \\
\hline & (2.09) & $(2.15)$ & $(1.86)$ & $(1.95)$ & $(0.37)$ & $(0.40)$ & $(0.50)$ & $(0.58)$ \\
\hline \multirow[t]{2}{*}{ Volatility } & 0.003 & 0.003 & 0.002 & 0.003 & 0.004 & 0.004 & 0.003 & 0.004 \\
\hline & $(0.63)$ & $(0.66)$ & $(0.46)$ & $(0.55)$ & $(1.24)$ & $(1.26)$ & (1.16) & $(1.24)$ \\
\hline \multirow[t]{2}{*}{ Alpha } & $-0.544 * * *$ & $-0.540^{* * *}$ & $-0.529 * * *$ & $-0.520 * * *$ & $-0.577 * * *$ & $-0.576^{* * *}$ & $-0.589 * * *$ & $-0.585^{* * *}$ \\
\hline & $(-4.15)$ & $(-4.13)$ & $(-4.06)$ & $(-3.99)$ & $(-6.01)$ & $(-5.99)$ & $(-6.15)$ & $(-6.09)$ \\
\hline \multirow[t]{2}{*}{ LOG(MC) } & $-0.004 * *$ & $-0.004 * *$ & $-0.004^{* *}$ & $-0.004 * *$ & $-0.006^{* * *}$ & $-0.006^{* * *}$ & $-0.005 * * *$ & $-0.005^{* * * *}$ \\
\hline & $(-2.19)$ & $(-2.20)$ & $(-2.09)$ & $(-2.18)$ & $(-4.38)$ & $(-4.39)$ & $(-4.34)$ & $(-4.40)$ \\
\hline \multirow[t]{2}{*}{$\mathrm{P} / \mathrm{B}$} & 0.006 & 0.006 & 0.005 & 0.005 & -0.021 & -0.022 & -0.023 & -0.023 \\
\hline & $(0.18)$ & $(0.16)$ & $(0.14)$ & $(0.13)$ & $(-1.49)$ & $(-1.50)$ & $(-1.62)$ & $(-1.62)$ \\
\hline \multirow[t]{2}{*}{ ROE } & $-0.117 * * *$ & $-0.117 * * *$ & $-0.118^{* * *}$ & $-0.118^{* * *}$ & $0.025 * * *$ & $0.025 * * *$ & $0.027 * * *$ & $0.027 * * *$ \\
\hline & $(-8.92)$ & $(-8.92)$ & $(-8.94)$ & $(-8.98)$ & (4.19) & $(4.20)$ & $(4.34)$ & $(4.36)$ \\
\hline \multirow[t]{2}{*}{ GROWTH } & -0.000 & -0.000 & -0.000 & -0.000 & -0.000 & -0.000 & -0.000 & -0.000 \\
\hline & $(-0.52)$ & $(-0.54)$ & $(-0.55)$ & $(-0.60)$ & $(-1.24)$ & $(-1.24)$ & $(-1.27)$ & $(-1.30)$ \\
\hline \multirow[t]{2}{*}{ EARN.Q } & -0.001 & -0.001 & -0.000 & -0.000 & -0.000 & -0.000 & -0.000 & -0.000 \\
\hline & $(-0.52)$ & $(-0.55)$ & $(-0.43)$ & $(-0.35)$ & $(-0.19)$ & $(-0.20)$ & $(-0.13)$ & $(-0.08)$ \\
\hline \multirow[t]{2}{*}{ LOG(D/E) } & 0.066 & 0.063 & 0.060 & 0.056 & 0.009 & 0.008 & 0.002 & -0.000 \\
\hline & $(1.01)$ & $(0.97)$ & $(0.92)$ & $(0.87)$ & $(0.17)$ & $(0.16)$ & $(0.03)$ & $(-0.00)$ \\
\hline Marginal effect & & $0.011 * * *$ & & $0.018^{* * *}$ & & $0.262 * * *$ & & $0.221^{* * *}$ \\
\hline Standard error & & 0.004 & & 0.006 & & 0.001 & & 0.003 \\
\hline Observations & 2,835 & 2,835 & 2,835 & 2,835 & 2,835 & 2,835 & 2,835 & 2,835 \\
\hline R-squared & 0.239 & 0.240 & 0.242 & 0.244 & 0.086 & 0.086 & 0.086 & 0.088 \\
\hline Number of firms & 831 & 831 & 831 & 831 & 831 & 831 & 831 & 831 \\
\hline Firm FE & YES & YES & YES & YES & YES & YES & YES & YES \\
\hline Year FE & YES & YES & YES & YES & YES & YES & YES & YES \\
\hline
\end{tabular}

Notes: The dependent variable in models 1-4 is the analysts' earnings forecast error scaled by price per share, ERROR = $\mid 100 *($ FEPS-NEPS $) / \mathrm{pt} \mid$ and in models $5-8$ is in analysts' forecasts dispersion scaled by price per share, DISPERSION it $=100 *($ FMAX - FMIN)/pt. We compute the marginal effects as the sum of the coefficients on $\log (\operatorname{Ex} . P)$ and Ex.SH* $\log ($ Ex.P) in model 2 and 6 and the sum of coefficients on $\log ($ L.P) and L.SH*Log(L.P) in models 4 and 8 together with the corresponding standard errors of these sums. The regressions control for fixed firm effects and year effects, and the corresponding t-statistics are calculated using standard errors adjusted for clusters in stock code. Coefficients on the year dummies are not reported to conserve space. Subsamples are divided based on the presence of executive/leadership shareholdings. Variable definitions follow table 2. $* * * \mathrm{p}<0.01, * * \mathrm{p}<0.05, * \mathrm{p}<0.1$. 
Table 5: Excess executive and leadership compensation and information asymmetry

\begin{tabular}{|c|c|c|c|c|}
\hline Model & (1) & (2) & (3) & (4) \\
\hline Dep. Var. & \multicolumn{2}{|c|}{ Forecast error } & \multicolumn{2}{|c|}{ Forecast dispersion } \\
\hline \multirow[t]{2}{*}{ Excess $\log ($ Ex.P) } & -0.254 & & $0.307 * * *$ & \\
\hline & $(-1.38)$ & & $(2.87)$ & \\
\hline \multirow[t]{2}{*}{ Excess $\log (\mathrm{L} . \mathrm{P})$} & & -0.283 & & $0.228^{* *}$ \\
\hline & & $(-1.43)$ & & $(2.01)$ \\
\hline \multirow[t]{2}{*}{ INS.SH } & -0.002 & -0.001 & -0.003 & -0.003 \\
\hline & $(-0.51)$ & $(-0.39)$ & $(-1.39)$ & $(-1.46)$ \\
\hline \multirow[t]{2}{*}{ SH.CON } & 0.005 & 0.004 & $0.014 * * *$ & $0.015^{* * *}$ \\
\hline & $(0.64)$ & $(0.51)$ & $(2.96)$ & $(3.03)$ \\
\hline \multirow[t]{2}{*}{ Volatility } & $0.017 * * *$ & $0.016^{* * *}$ & -0.003 & -0.003 \\
\hline & $(3.55)$ & $(3.51)$ & $(-0.94)$ & $(-1.23)$ \\
\hline \multirow[t]{2}{*}{ Alpha } & $-1.237 * * *$ & $-1.231 * * *$ & $-0.410 * * *$ & $-0.414 * * *$ \\
\hline & $(-7.96)$ & $(-7.93)$ & $(-4.54)$ & $(-4.55)$ \\
\hline \multirow[t]{2}{*}{$\mathrm{P} / \mathrm{B}$} & $-0.157 * * *$ & $-0.160 * * *$ & $-0.030 * *$ & $-0.032 * *$ \\
\hline & $(-6.03)$ & $(-6.06)$ & $(-2.37)$ & $(-2.54)$ \\
\hline \multirow[t]{2}{*}{ GROWTH } & -0.000 & -0.000 & -0.000 & -0.000 \\
\hline & $(-0.35)$ & $(-0.33)$ & $(-0.61)$ & $(-0.65)$ \\
\hline \multirow[t]{2}{*}{ EARN.Q } & -0.001 & -0.001 & -0.001 & -0.000 \\
\hline & $(-0.65)$ & $(-0.71)$ & $(-0.69)$ & $(-0.58)$ \\
\hline \multirow[t]{2}{*}{ LOG(D/E) } & $0.209 * * *$ & $0.208^{* * *}$ & $0.100 * *$ & $0.091 * *$ \\
\hline & $(2.99)$ & $(2.99)$ & $(2.18)$ & $(2.00)$ \\
\hline Observations & 2,831 & 2,831 & 2,615 & 2,615 \\
\hline R-squared & 0.100 & 0.100 & 0.050 & 0.048 \\
\hline Number of firms & 831 & 831 & 831 & 831 \\
\hline Firm FE & YES & YES & YES & YES \\
\hline Year FE & YES & YES & YES & YES \\
\hline
\end{tabular}

Notes: The regressions control for fixed firm effects and year effects, and the corresponding t-statistics are calculated using standard errors adjusted for clusters in stock code. Coefficients on the year dummies are not reported to conserve space. The dependent variable for models 1 and 2 is analysts' forecast error, and for models 3 and 4 is forecasts dispersion. Variable definitions follow table $2 . * * * \mathrm{p}<0.01, * * \mathrm{p}<0.05, * \mathrm{p}<0.1$.

We adopt a fixed-effects model to estimate the predicted managerial cash compensation based on determinants including managerial equity shareholding Shareholding $i t$ and board independence $B . I N D_{i t}$ as measures of managerial structural power in determining their compensations, Tobin's $\mathrm{Q}$ ratio as a proxy for firm growth opportunities, return on equity $R O E_{i t}$ as profitability associated pay reward, and firm size measured by the $\log$ of market capitalization $L O G(M C)_{i t}$.

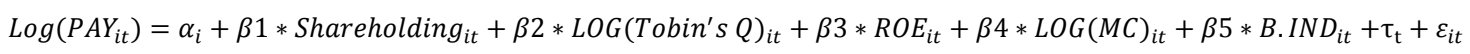

The model includes fixed firm effects $\alpha_{i}$ and fixed time effects $\tau_{t}$, and R-squared of the prediction regressions are 37\% and $29 \%$ for executives cash compensation and average per person leadership cash compensation, respectively. The excessive cash compensations for executives and firm leaders are then calculated as the difference between their actual log pay minus the predicted log pay from the model predictions. 
Table 6: Robustness tests

\begin{tabular}{|c|c|c|c|c|}
\hline \multicolumn{5}{|c|}{ Panel A: Using scaled prediction errors and dispersions } \\
\hline Model & 1 & 2 & 3 & 4 \\
\hline Dep. Var. & Forecast error & Forecast error & Forecast dispersion & Forecast dispersion \\
\hline \multirow[t]{2}{*}{ Excess $\log (\mathrm{Ex} . \mathrm{P}) / \mathrm{MC}$} & -2.405 & & $2.269 * *$ & \\
\hline & $(-1.49)$ & & $(2.49)$ & \\
\hline \multirow[t]{2}{*}{ Excess $\log (\mathrm{L} . \mathrm{P}) / \mathrm{MC}$} & & -2.748 & & $1.597 * *$ \\
\hline & & $(-1.61)$ & & $(2.01)$ \\
\hline Controls & YES & YES & YES & YES \\
\hline Firm FE & YES & YES & YES & YES \\
\hline Year FE & YES & YES & YES & YES \\
\hline Observations & 2,831 & 2,831 & 2,831 & 2,831 \\
\hline R-squared & 0.100 & 0.100 & 0.049 & 0.047 \\
\hline Number of firms & 831 & 831 & 831 & 831 \\
\hline \multicolumn{5}{|c|}{ Panel B: Controlling for predictability of earnings } \\
\hline Model & 1 & 2 & 3 & 4 \\
\hline Dep. Var. & Forecast error & Forecast error & Forecast dispersion & Forecast dispersion \\
\hline \multirow[t]{2}{*}{ Excess $\log ($ Ex.P) } & 0.054 & & $0.312 * *$ & \\
\hline & $(0.20)$ & & $(2.17)$ & \\
\hline \multirow[t]{2}{*}{ Excess $\log (\mathrm{L} . \mathrm{P})$} & & 0.125 & & $0.233^{* *}$ \\
\hline & & $(0.40)$ & & $(1.98)$ \\
\hline \multirow[t]{2}{*}{ Lag1_EPS } & $-1.708^{* *}$ & $-1.745^{* *}$ & $0.339 * *$ & $0.350 * *$ \\
\hline & $(-2.49)$ & $(-2.50)$ & $(2.02)$ & $(2.08)$ \\
\hline \multirow[t]{2}{*}{$\mathrm{D} / \mathrm{P}$} & -0.049 & -0.048 & $0.244 * * *$ & $0.254 * * *$ \\
\hline & $(-0.59)$ & $(-0.59)$ & $(4.75)$ & $(4.88)$ \\
\hline \multirow[t]{2}{*}{ Non-trade } & 0.007 & 0.006 & -0.005 & -0.005 \\
\hline & $(0.63)$ & $(0.58)$ & $(-0.94)$ & $(-1.01)$ \\
\hline Controls & Yes & Yes & Yes & Yes \\
\hline Firm FE & YES & YES & YES & YES \\
\hline Year FE & YES & YES & YES & YES \\
\hline Observations & 2,831 & 2,831 & 2,615 & 2,615 \\
\hline R-squared & 0.170 & 0.172 & 0.156 & 0.156 \\
\hline Number of firms & 831 & 831 & 831 & 831 \\
\hline
\end{tabular}

This table shows robustness tests using scaled excess compensation measures in Panel A and results further controlling for the predictability of earnings in Panel B. In panel A, the excess compensation measures are computed using scaled executive cash pay scaled by the firm market capitalization Ex.P/MC and the leadership cash pay scaled by the firm market capitalization L.P/MC, respectively. The compensation prediction model follows that of Table 5. In panel B, we further control for the random-walk earnings prediction model using 1-year lagged earnings per share Lag1_EPS, and dividend yield $\mathrm{D} / \mathrm{P}$. In addition, we further control for the percentage of non-tradable state-shares and legal person shares in the models. Other control variables follow table 5 regressions. 